\title{
Barriers and facilitators to self-care in chronic heart failure: a meta-synthesis of qualitative studies
}

Soraya Siabani ${ }^{1,2^{*}}$, Stephen R Leeder ${ }^{1}$ and Patricia M Davidson ${ }^{3}$

\begin{abstract}
Chronic heart failure (CHF) is a costly condition that places large demands on self-care. Failure to adhere with self-care recommendations is common and associated with frequent hospitalization. Understanding the factors that enable or inhibit self-care is essential in developing effective health care interventions. This qualitative review was conducted to address the research question, "What are the barriers and facilitators to self-care among patients with CHF?" Electronic databases including Medline, EMBASE, CINAHL, Web of Science, Scopus and Google scholar were searched. Articles were included if they were peer reviewed (1995 to 2012), in English language and investigated at least one contextual or individual factor impacting on self-care in CHF patients > 18years. The criteria defined by Kuper et al. including clarity and appropriateness of sampling, data collection and data analysis were used to appraise the quality of articles. Twenty-three articles met the inclusion criteria. Factors impacting on self-care were included factors related to symptoms of CHF and the self-care process; factors related to personal characteristics; and factors related to environment and self-care system. Important factors such as socioeconomic situation and education level have not been explored extensively and there were minimal data on the influence of age, gender, self-confidence and duration of disease. Although there is an emerging literature, further research is required to address the barriers and facilitators to self-care in patients with CHF in order to provide an appropriate guide for intervention strategies to improve self-care in CHF.
\end{abstract}

Keywords: Congestive heart failure; CHF; Self-management; Treatment adherence; Compliance; Self-care determinants; Qualitative review

\section{Introduction}

Chronic heart failure (CHF) is a chronic progressive condition where the heart fails to meet the body's metabolic demands. CHF is an increasingly common and burdensome illness especially among older people and is a major cause of mortality, morbidity and poor quality of life worldwide (Go et al. 2013; AIHW 2011). The prevalence of CHF has been reported as $0.4 \%$ to $2 \%$ in the general population and between $2.3 \%$ to over $16 \%$ among those aged >75years (Go et al. 2013; AIHW 2011; Heidenreich et al. 2011; Anguita Sanchez et al. 2008; Masoudi et al. 2002). A large proportion of health

\footnotetext{
*Correspondence: ssia5034@uni.sydney.edu.au

${ }^{1}$ Victor Coppleson Building - D02, Menzies Center for Health Policy, Medical

School, The University of Sydney, Sydney, Australia

${ }^{2}$ School of Health, Kermansha University of Medical Sciences, Kermanshah, Iran

Full list of author information is available at the end of the article
}

care resources increasingly goes towards treating cardiovascular diseases (CVD), especially CHF. Many of these costs are attributed to hospitalization (Go et al. 2013; Berry et al. 2001; Chen et al. 2010). Hospitalization for CHF exacerbations could often be prevented by care plans considering self-care as a core for their health programs (Klersy et al. 2011; Ditewig et al. 2010; Hertzog et al. 2010). Furthermore, effective self-care has been critical in promoting optimal outcomes in CHF (Chen et al. 2010; Grady 2008) and reducing mortality rates (Ditewig et al. 2010).

Self-care in CHF is described as a naturalistic decisionmaking process enabling engagement with healthy behaviors such as daily monitoring and adherence to the plan of care (self-care maintenance), and adequate management of symptoms and evaluation of applied treatment actions (self-care management) (Riegel et al. 2009; Moser et al. 
2012). Despite the advantages of self-care, patients with CHF, especially older people, face numerous difficulties in achieving optimal quality of self-care (Powell et al. 2008; Muzzarelli et al. 2010; Sayers et al. 2008).

Appreciating the factors that enable or inhibit self-care is critical in developing effective recommendations for self-care. However, there is no comprehensive study which clarifies these factors. For this purpose, reviewing qualitative studies is important in understanding patients' experiences (Dixon-Woods et al. 2005; Thorne et al. 2004; Barnett-Page \& Thomas 2009), health seeking behaviours (Murray 1998) and providing a clear insight into barriers and facilitators through uncovering beliefs and motivations of individuals (Dixon-Woods et al. 2005; Kent \& Fineout-Overholt 2008). The aim of this meta-synthesis review (Sandelowski \& Barroso 2003) was to review studies that identify barriers and facilitators to self-care in patients with CHF.

\section{Method and subjects Search strategy}

A meta-synthesis of qualitative studies was undertaken to address the research question; what are the facilitators or barriers to self-care in patients with CHF? Electronic data bases of Medline, Embase, CINAHL, Web of Science, Scopus and Google scholar were systematically searched for articles. A combination of MeSH terms and text words, under supervision of a health librarian, was used to explore each database. To increase the sensitivity of the search strategy and avoid missing valuable studies, a wide range of possible terms for self-care were used in combination with $\mathrm{MeSH}$ terms for chronic heart failure (e.g. heart failure and self-care). The most key words, terms and subject headings were; self-management, self-maintenance, self-monitoring, self-regulation, help-seeking, adherence , compliance, daily weight monitoring, sodium limitation, fluid restriction, sign, symptom, behavior, barriers, facilitators, help-seeking, physical activity and exercise.

\section{Inclusion criteria and Quality assessment}

Qualitative studies were included if they were peer-reviewed and published between1995 and June 2012. This timeframe was chosen because it corresponded to an upsurge in the discourse on self-management. Studies were in the English language and investigated at least one contextual or individual factor impacting on self-care in patients with $\mathrm{CHF}>18$ years. The wide variety of qualitative methods made it difficult to compare and critique such research (Sandelowski \& Barroso 2003; Sandelowski \& Emden 1997). The absence of commonly applicable criteria to use in critically appraising these papers, as might be used in a systematic review of quantitative studies with regard to the sample size, process of randomization, and assessment of statistical significance limited the critical process
(Solomon 2009). Of available guidelines for this purpose (Kuper \& Levinson 2008; CG 2010; Collingridge \& Gantt 2008; Kitto et al. 2008), criteria from (Kuper \& Levinson 2008) were used (Table 1). Appraising the paper from (Falk et al. 2007), by way of example, is presented in Table 1. Based on these criteria, studies were ranked as very good, good, acceptable or unclear (Table 2, organized chronologically) Articles that had clear research aims and met at least four of the six appraisal criteria from (Kuper \& Levinson 2008) were included. Two criteria; possibility of applying the results of study in other settings and addressing potential ethical issues were not taken into consideration as exclusion criteria because the generalizability of results emerging from qualitative studies is controversial (Myers 2000), and most article addressed ethical issues even if they did not explain details in reports, given the conventional requirement of most journals for evidence of ethical clearance of studies submitted for publication. Finally, Twenty-three articles were found to meet the inclusion criteria (Figure 1).

This study was a part of research that has been approved by the ethics committee of the University of Sydney.

\section{Findings}

Participants in the reviewed studies included 477 patients (289 male and 188 female) between 38 to 98year old livings with CHF. Most studies included men and women with the exception of Martensson et al. 1997 who selected only 12 males and Sheahan \& Fields 2008 who had an exclusively female sample $(n=33)$. Time since diagnosis of CHF in eight studies was a minimum of six months (Falk et al. 2007; Schnell et al. 2006; Clark et al. 2009; Ming et al. 2011; Dickson et al. 2012; Riegel et al. 2010b), while other investigators included cases with a diagnosis duration of one month or more. Six studies did not report New York Heart Association (NYHA) functional classification of their participants (Buetow et al. 2001; Scotto 2005; Rucker-Whitaker et al. 2006; Davidson et al. 2007; Kaholokula et al. 2008; Sheahan \& Fields 2008). Most other investigators included patients with functional classes II, III and IV. However, about 75\% of participants were in advanced stages of CHF, classes III or IV (Martensson et al. 1997; Buetow et al. 2001; Horowitz et al. 2004; Riegel et al. 2006; Rucker-Whitaker et al. 2006; Riegel et al. 2007). Seven studies (Riegel \& Carlson 2002; Scotto 2005; Riegel et al. 2006; Rucker-Whitaker et al. 2006; Schnell et al. 2006; Riegel et al. 2007; Sheahan \& Fields 2008) reported one or more comorbidities (e.g. diabetes) in their subjects. The participants of three studies included doctors or nurses (as careers, not as patients) along with patients and their families (Table 2). 
Table 1 Criteria from Kuper \& Levinson (2008) applied in appraising studies; a study cunducted by Falk et al. (2007) was appraised as an example

Was what the researchers did clear?

Was the sample used appropriate to its research question?

Were the data collected appropriately?

Were the data analyzed appropriately?

Can the results of this study be transferred to other settings?

Did the study adequately address potential ethical issues?
Yes, researchers explicated aim, methodology (e.g. sampling, inclusion criteria, data gathering) results and analysis with a clear scenario.

Yes, it was a phenomenology study. Sampling has clearly been articulated. 17 patients living with CHF who had personal experiences about HF to address the research question. Sample size was broad enough to capture many aspects of the CHF. However, they did not acknowledge socioeconomic situation and other associated factors

Yes, setting had been justified for data collection. Data were collected through recorded interviewing that is appropriate for exploring experiences of stakeholders in a phenomenology. Question as "what do you mean?" was used that is fit for phenomenological studies. Data collection was done by nurses familiar with CHF and continued to achieve data saturation.

Yes, The study had a clear description of data analysis process. Subcategories, categories and themes were derived from data by separate interpreters and then compared and combined. Some quotas from original data were used for supporting findings.

Researchers did not discuss transferring results to other populations; however, they gave recommendations for caregivers and patients in general.

Yes, researchers had a comprehensive presentation of ethical issues including achieving approval from ethics committee and chief physician plus informing the participants about study followed by consent from them
In Table 3, where articles were organized chronologically, the important findings of facilitators and barriers to self-care in patients with CHF that emerged from the 23 studies were summarized. Results showed that atypical and puzzling symptoms of CHF, complexity of the self-care process, insufficient knowledge, comorbidity burden, cognitive decline and memory loss, depression and anxiety, poor communication skills, adverse coping strategies (avoidance and denial) hinder self-care in patients with CHF. On the other hand, supportive environments, disavowal coping strategy, trust in health care providers, spiritual beliefs and optimism were identified as positive contributing factors to self-care in these patients. The role of personal values, cultural issues (Martensson et al. 1997; Dickson et al. 2012) and acceptance (Riegel \& Carlson 2002) were controversial in different studies, where some reported they made a positive contribution and others found a negative contribution to $\mathrm{CHF}$ self-care. In general, barriers and facilitators fell into three categories: a. factors related to the symptoms of CHF and self-care processes; b. factors related to personal characteristics; and c. environmental and health care givers' factors.

\section{Facilitators and barriers related to CHF syndrome and the process of self-care}

Buetow et al. reported that recognizing CHF symptoms, especially atypical symptoms such as dizziness, fatigue, sleepiness, cognitive decline and loss of consciousness, was difficult for patients with CHF (Buetow et al. 2001). Patients found it difficult to interpret (Ming et al. 2011) or respond (Granger et al. 2009) to complex symptoms, especially in combination. Horowitz et al. reported that patients found difficulty either in recognizing or responding to symptoms in an exacerbation (Horowitz et al. 2004). Furthermore, suffering from such symptoms reduced the ability of patients to engage in efficacious self-care (Clark et al. 2009; Granger et al. 2009). Even patients who had sufficient knowledge about HF and self-care frequently were unable to manage exacerbations of HF symptoms (Falk et al. 2007; Horowitz et al. 2004; Scotto 2005; Riegel et al. 2006). Also, functional limitation and dependency linked to CHF have been reported as serious barriers to self-care in patients with advanced HF (classes III and IV) by three studies (Martensson et al. 1997; Riegel \& Carlson 2002; Granger et al. 2009).

Complexity of self-care processes and difficulty in adhering to dietary change was another barrier to self-care in patients living with CHF (Riegel \& Carlson 2002; Sheahan \& Fields 2008; Granger et al. 2009). Following a diagnosis of $\mathrm{CHF}$, the prescribed actions can seem complex and require situational skills (Dickson \& Riegel 2009). Granger et al. and Dickson et al. found that physicians and patients have differing perceptions of instructions and that as a result patients were at times unable to understand and apply what their doctor instructed them to do. (Granger et al. 2009; Dickson et al. 2012)

Facilitators and barriers related to personal characteristics The lack of knowledge of CHF patients, especially regarding diet and salt restriction, and misconceptions about $\mathrm{CHF}$ and its symptoms leading to failure of understanding of the relationship between disease and symptoms, were prominent themes as barriers to self-care in the reviewed studies (Riegel \& Carlson 2002; Horowitz et al. 2004; 
Table 2 Quality of studies included in a meta-synthesis of researches relating to self-care in patients with CHF ( $\mathrm{n}=23$ )

\begin{tabular}{|c|c|c|c|c|c|c|c|c|c|}
\hline $\begin{array}{l}\text { Author /year / } \\
\text { country / reference } \\
\text { number }\end{array}$ & $\begin{array}{l}\text { Study design / } \\
\text { tools/population }\end{array}$ & Aim & $\begin{array}{l}\text { Was what the } \\
\text { researchers } \\
\text { did clear? }\end{array}$ & $\begin{array}{l}\text { Was the aim / } \\
\text { research question } \\
\text { clear? }\end{array}$ & $\begin{array}{l}\text { Is the sample } \\
\text { used appropriate } \\
\text { to its research question? }\end{array}$ & $\begin{array}{l}\text { Were the data } \\
\text { collected } \\
\text { appropriately? }\end{array}$ & $\begin{array}{c}\text { Were the } \\
\text { data analyzed } \\
\text { appropriately? }\end{array}$ & $\begin{array}{l}\text { Can the } \\
\text { results of } \\
\text { this study be } \\
\text { transferred to } \\
\text { other settings? }\end{array}$ & $\begin{array}{l}\text { Does the study } \\
\text { adequately } \\
\text { address potential } \\
\text { ethical issues? }\end{array}$ \\
\hline $\begin{array}{l}\text { Martensson et al. } \\
\text { (1997) Sweden }\end{array}$ & $\begin{array}{l}\text { Phenomenology/ } \\
\text { Interview } \\
\text { ( } n=12 \text { patients) }\end{array}$ & $\begin{array}{l}\text { To investigate how } \\
\text { patients conceive their } \\
\text { life situation }\end{array}$ & $G^{* *}$ & G & $A^{* * *}$ & $V G^{*}$ & G & $U^{* * * *}$ & G \\
\hline $\begin{array}{l}\text { Rogers et al. (2000) } \\
\text { United Kingdom }\end{array}$ & $\begin{array}{l}\text { In-depth interview } \\
(n=27 \text { patients })\end{array}$ & $\begin{array}{l}\text { Investigate patients' } \\
\text { need for information }\end{array}$ & G & VG & G & G & A & U & U \\
\hline $\begin{array}{l}\text { Buetow et al. } \\
\text { (2001) New Zealand }\end{array}$ & $\begin{array}{l}\text { Narrative/ } \\
\text { Semi-structured } \\
\text { questionnaire/ } \\
\text { Interview } \\
\text { ( } \mathrm{n}=62 \text { patients) }\end{array}$ & $\begin{array}{l}\text { To illustrate how } \\
\text { patients cope with } \\
\text { their illness }\end{array}$ & G & VG & G & VG & G & A & U \\
\hline $\begin{array}{l}\text { Riegel \& Carlson } \\
\text { (2002) USA }\end{array}$ & $\begin{array}{l}\text { Interview/ } \\
\text { Structured } \\
\text { questionnaire } \\
\text { ( } n=26 \text { patients) }\end{array}$ & $\begin{array}{l}\text { To explain better } \\
\text { adaptation in some } \\
\text { people }\end{array}$ & VG & VG & G & VG & G & A & G \\
\hline $\begin{array}{l}\text { Horowitz et al. } \\
\text { (2004) USA }\end{array}$ & $\begin{array}{l}\text { Grounded theory/ } \\
\text { Semi-structured } \\
\text { interview } \\
\text { ( } n=19 \text { patients) }\end{array}$ & $\begin{array}{l}\text { To elucidate patients' } \\
\text { belief and knowledge } \\
\& \text { understand factors } \\
\text { underling self-care } \\
\text { routines }\end{array}$ & VG & G & A & VG & G & U & G \\
\hline Scotto (2005) USA & $\begin{array}{l}\text { Phenomenology/ } \\
\text { Interview } \\
\text { ( } n=14 \text { patients) }\end{array}$ & $\begin{array}{l}\text { To explore the } \\
\text { experience of patients } \\
\text { living with HF and } \\
\text { their adherence to } \\
\text { prescribed regimens }\end{array}$ & VG & VG & VG & G & G & A & G \\
\hline $\begin{array}{l}\text { Eldh et al. } \\
\text { (2006) Sweden }\end{array}$ & $\begin{array}{l}\text { Narrative/ } \\
\text { Interview }+ \\
\text { observation } \\
\text { ( } n=4 \text { patients }+2 \\
\text { Nurses) }\end{array}$ & $\begin{array}{l}\text { To explore patients' } \\
\text { participation/ } \\
\text { non- participation } \\
\text { in a CHF care program }\end{array}$ & G & G & A & G & VG & U & VG \\
\hline $\begin{array}{l}\text { Riegel et al. } \\
\text { (2006) USA }\end{array}$ & $\begin{array}{l}\text { Mixed method/ } \\
\text { Interview } \\
\text { ( } \mathrm{n}=15 \text { patients) }\end{array}$ & $\begin{array}{l}\text { To evaluate a } \\
\text { motivational } \\
\text { interviewing } \\
\text { intervention and identify } \\
\text { the mechanisms by } \\
\text { which it influenced HF } \\
\text { self-care }\end{array}$ & G & VG & A & A & G & $\mathrm{N}^{* * * * * *}$ & G \\
\hline $\begin{array}{l}\text { Rucker-Whitaker } \\
\text { et al. (2006) USA }\end{array}$ & $\begin{array}{l}\text { Focus group } \\
\text { ( } n=25 \text { patients) }\end{array}$ & $\begin{array}{l}\text { To understand from the } \\
\text { patient perspective what } \\
\text { factors promote/limit } \\
\text { retention in a } \\
\text { self-management } \\
\text { improvement program }\end{array}$ & A & G & A & A & A & N & U \\
\hline
\end{tabular}


Table 2 Quality of studies included in a meta-synthesis of researches relating to self-care in patients with $\mathrm{CHF}(\mathrm{n}=\mathbf{2 3})(\mathrm{Continued})$

\begin{tabular}{|c|c|c|c|c|c|c|c|c|c|}
\hline $\begin{array}{l}\text { Schnell et al. } \\
\text { (2006) Canada }\end{array}$ & $\begin{array}{l}\text { Semi-structured } \\
\text { interview } \\
(\mathrm{n}=11 \text { patients) }\end{array}$ & $\begin{array}{l}\text { To explore self-care } \\
\text { experience living with } \\
\text { CHF }\end{array}$ & $\mathrm{G}$ & A & G & $G$ & G & G & G \\
\hline $\begin{array}{l}\text { Falk et al. } \\
\text { (2007) Sweden }\end{array}$ & $\begin{array}{l}\text { Phenomenology/ } \\
\text { Interview }(n=17)\end{array}$ & $\begin{array}{l}\text { To describe how } \\
\text { persons living with } \\
\text { CHF perceived the } \\
\text { maintenance of their } \\
\text { daily life }\end{array}$ & VG & G & G & VG & VG & $U$ & U \\
\hline $\begin{array}{l}\text { Davidson et al. } \\
\text { (2007) Australia }\end{array}$ & $\begin{array}{l}\text { Interview } \\
\text { (triangulation study) } \\
(\mathrm{n}=17 \text { patients }+13 \\
\text { family }+16 \\
\text { key-informants) }+ \\
\text { literature }\end{array}$ & $\begin{array}{l}\text { To describe health } \\
\text { patterns, information } \\
\text { needs, and adjustment } \\
\text { process for overseas- } \\
\text { born people with heart } \\
\text { failure living in } \\
\text { Australia }\end{array}$ & $\mathrm{G}$ & $A$ & G & VG & G & $A$ & VG \\
\hline $\begin{array}{l}\text { Riegel et al. } \\
\text { (2007) USA }\end{array}$ & $\begin{array}{l}\text { Mixed method/ } \\
\text { Interview } \\
(\mathrm{n}=29 \text { patients) }\end{array}$ & $\begin{array}{l}\text { To describe how } \\
\text { expertise in CHF } \\
\text { self-care develops }\end{array}$ & $\mathrm{G}$ & VG & VG & $G$ & G & $\mathrm{G}$ & U \\
\hline $\begin{array}{l}\text { Kaholokula et al. } \\
\text { (2008) USA }\end{array}$ & $\begin{array}{l}\text { Focus group } \\
\text { ( } \mathrm{n}=11 \text { patients }+ \\
25 \text { nurses) }\end{array}$ & $\begin{array}{l}\text { To describe health } \\
\text { beliefs, attitudes, } \\
\text { practices and social } \\
\text { and family relations } \\
\text { important in CHF } \\
\text { treatment }\end{array}$ & VG & VG & G & $\mathrm{G}$ & G & $N$ & G \\
\hline $\begin{array}{l}\text { Rodriguez et al. } \\
\text { (2008) USA }\end{array}$ & $\begin{array}{l}\text { Grounded theory/ } \\
\text { Semi-structured } \\
\text { telephone interview } \\
\text { ( } n=25 \text { patients) }\end{array}$ & $\begin{array}{l}\text { To explore patients' } \\
\text { knowledge about } \mathrm{CHF} \\
\text { diagnosis and their } \\
\text { understanding of } \\
\text { cardiac care providers' } \\
\text { recommendations }\end{array}$ & $A$ & G & A & $A$ & G & $N$ & VG \\
\hline $\begin{array}{l}\text { Sheahan \& Fields } \\
\text { (2008) USA }\end{array}$ & $\begin{array}{l}\text { Semi-structured } \\
\text { questionnaire/ } \\
\text { Focus group } \\
\text { ( } n=33 \text { patients) }\end{array}$ & $\begin{array}{l}\text { To explore factors } \\
\text { associated with } \\
\text { sodium-restricted diet }\end{array}$ & A & G & G & $G$ & G & G & VG \\
\hline $\begin{array}{l}\text { Dickson et al. } \\
\text { (2008) USA }\end{array}$ & $\begin{array}{l}\text { Mixed method/ } \\
\text { Semi-structured } \\
\text { interview } \\
\text { ( } \mathrm{n}=41 \text { patients) }\end{array}$ & $\begin{array}{l}\text { To identify the } \\
\text { influences of attitudes } \\
\text { and self-efficacy on HF } \\
\text { self-care management }\end{array}$ & VG & VG & VG & $\mathrm{G}$ & G & G & G \\
\hline $\begin{array}{l}\text { Clark et al. } \\
\text { (2009) USA }\end{array}$ & $\begin{array}{l}\text { Semi-structured } \\
\text { interview }(n=42 \\
\text { patients }+30 \\
\text { informal caregiver) }\end{array}$ & $\begin{array}{l}\text { To explore factors } \\
\text { (perceived by patients } \\
\text { and health givers) } \\
\text { influencing willingness } \\
\text { and capacity to } \\
\text { manage CHF }\end{array}$ & $\mathrm{G}$ & VG & G & $G$ & A & $\mathrm{G}$ & $V G$ \\
\hline $\begin{array}{l}\text { Dickson \& Riegel } \\
\text { (2009) USA }\end{array}$ & $\begin{array}{l}\text { Qualitative } \\
\text { descriptive } \\
\text { meta- analysis }\end{array}$ & $\begin{array}{l}\text { To assess self-care skill } \\
\text { in CHF patients and }\end{array}$ & $\mathrm{G}$ & G & G & $G$ & A & U & U \\
\hline
\end{tabular}


Table 2 Quality of studies included in a meta-synthesis of researches relating to self-care in patients with $\mathrm{CHF}(\mathrm{n}=\mathbf{2 3})(\mathrm{Continued})$

\begin{tabular}{|c|c|c|c|c|c|c|c|c|c|}
\hline & $\begin{array}{l}\text { of their } 3 \text { studies } \\
\text { ( } \mathrm{n}=85 \text { patients) }\end{array}$ & $\begin{array}{l}\text { explore their skill } \\
\text { needs }\end{array}$ & & & & & & & \\
\hline $\begin{array}{l}\text { Granger et al. } \\
\text { (2009) USA }\end{array}$ & $\begin{array}{l}\text { Open-ended } \\
\text { questionnaire/ } \\
\text { In-depth interview } \\
\text { ( } n=6 \text { patients and } \\
6 \text { physicians) }\end{array}$ & $\begin{array}{l}\text { To explore patients' } \\
\text { and their physicians' } \\
\text { perspectives about } \\
\text { adherence and how } \\
\text { the exchange of } \\
\text { information between } \\
\text { them is experienced } \\
\text { by each group }\end{array}$ & $\mathrm{G}$ & G & $A$ & A & G & $U$ & VG \\
\hline $\begin{array}{l}\text { Riegel et al. } \\
\text { (2010a) USA }\end{array}$ & $\begin{array}{l}\text { Mixed method/ } \\
\text { Interview/ Open- } \\
\text { ended question } \\
(n=27)\end{array}$ & $\begin{array}{l}\text { To describe CHF } \\
\text { self-care in men and } \\
\text { women and to identify } \\
\text { gender-specific barriers } \\
\text { and facilitators } \\
\text { influencing CHF } \\
\text { self-care }\end{array}$ & VG & VG & $A$ & VG & G & $N$ & VG \\
\hline $\begin{array}{l}\text { Ming et al. } \\
\text { (2011) Malaysia }\end{array}$ & $\begin{array}{l}\text { Semi-structured } \\
\text { interview } \\
(\mathrm{n}=20 \text { patients })\end{array}$ & $\begin{array}{l}\text { To explore patients' } \\
\text { experiences of } \\
\text { self-management } \\
\text { and identify factors } \\
\text { influencing patients' } \\
\text { adherence to } \\
\text { medications }\end{array}$ & $\mathrm{G}$ & G & $\mathrm{G}$ & G & G & G & VG \\
\hline $\begin{array}{l}\text { Dickson et al. } \\
\text { (2012) published } \\
\text { online) USA }\end{array}$ & $\begin{array}{l}\text { Mixed method/ } \\
\text { Interview/Open- } \\
\text { ended question } \\
(n=30)\end{array}$ & $\begin{array}{l}\text { To describe the } \\
\text { cultural beliefs about } \\
\text { self-care, identify social } \\
\text { factors influencing } \\
\text { self-care and how } \\
\text { these factors influence } \\
\text { self-care practices }\end{array}$ & VG & G & G & G & G & G & G \\
\hline
\end{tabular}

* VG $=$ Very good ${ }^{* *} \mathrm{G}=$ Good ${ }^{* * *} \mathrm{~A}=$ Acceptable ${ }^{* * * *} \mathrm{U}=$ Unclear ${ }^{* * * *} \mathrm{~N}=$ No 


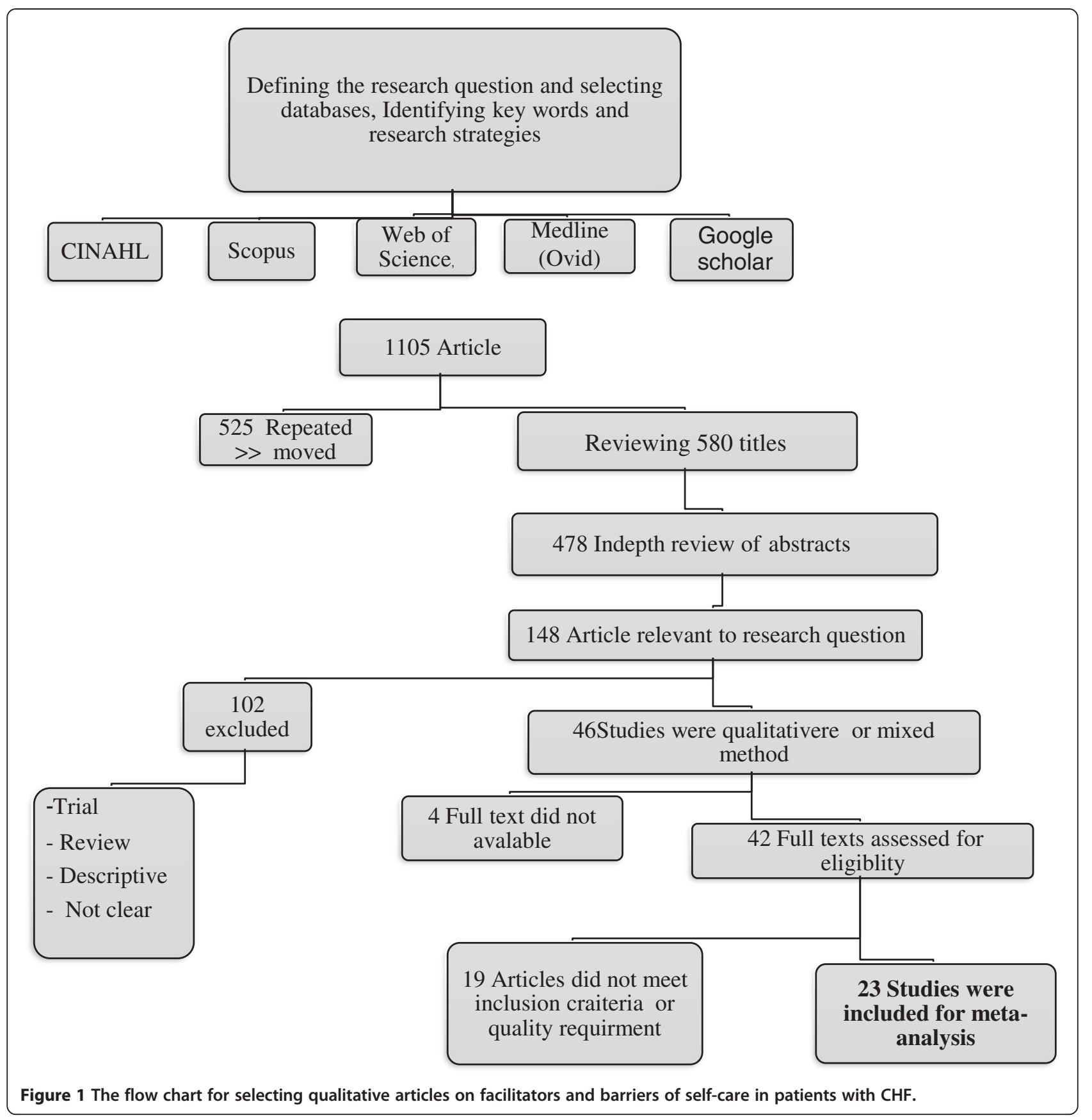

Eldh et al. 2006; Rodriguez et al. 2008; Sheahan \& Fields 2008; Ming et al. 2011). Patients identified health awareness and understanding the consequences of ignoring the treatment plan and indicators of a worsening condition as facilitator stimulating care for themselves (Falk et al. 2007; Martensson et al. 1997; Schnell et al. 2006). Regarding duration of $\mathrm{CHF}$, only one study reported that patients with long- standing CHF fared better than those recently diagnosed (Dickson et al. 2008). Using a disavowal coping strategy helped patients to affirm their physical health (Martensson et al. 1997; Buetow et al. 2001). However, using avoidance and denial reduced the capability of patients to care for themselves (Buetow et al. 2001; Riegel \& Carlson 2002; Eldh et al. 2006; Rucker-Whitaker et al. 2006; Kaholokula et al. 2008). Acceptance had two contradictory consequences; as a barrier (Falk et al. 2007; Buetow et al. 2001; Riegel \& Carlson 2002) and as a facilitator (Buetow et al. 2001; Riegel \& Carlson 2002; Scotto 2005). Also, depression (Riegel \& Carlson 2002; Riegel et al. 2007), anxiety (Rucker-Whitaker et al. 2006) and hopelessness were found to be negative factors for self-care maintenance, self-care management and self-care 
Table 3 Barriers and facilitators to self-care in chronic heart failure

\section{Author / Year/ Country / Ref}

Martensson et al. (1997) Sweden

Buetow et al. (2001) New Zealand

Riegel \& Carlson (2002) USA

Horowitz et al. (2004) USA

Scotto (2005) USA

Eldh et al. (2006) Sweden

Riegel et al. (2006) USA

Rucker-Whitaker et al. (2006) USA

Schnell et al. (2006) Canada

Barriers /and the behaviours they affected

- Physical limitation, feeling lack of energy / physical activity

- Hopelessness / decision making and motivation for management symptom

- Short term memory loss and confusion / taking medicinel

- Misconception about CHF / medical and regimen adherence

- Acceptance / decision making

- Lack of facility / access to medical care

- Avoidance, acceptance and denial / to obtain new information for caring themselves, and participate in decision making

- Multiple medicine, side effects of medicine / adherence to treatment

- Lack of knowledge / adherence to regimen and exercise

- Atypical symptom and complexity of symptom / failing in following recommended diet

- Negative emotion and no environment support/ motivation

- Comorbidity / complexity of self-care and difficulty in symptom recognition

- Inadequate information (about CHF, its symptoms and their management)/ symptom recognition and definition of source of exacerbation symptom + symptom monitoring + receiving medical care

- Conflict between values of patients and nurses / not accepting new information and recommendation

- Insufficient knowledge of educators and nurses / patients' knowledge and skill for self-care

- Lack of knowledge / specially regarding diet and salt restriction

- Denial and anxiety / taking medicine

Dissatisfaction with received care / failed perceived benefit of self-care action such salt limitation

Hopelessness / motivation for physical activity and dietary regimen

\section{Facilitators/ and the behaviors they affected}

- Awareness of threat / physical activity

- Environmental support/ self-confidence

- Coping strategies of disavowal / taking medication and following prescriptions

- Supportive strategies; emotionally and tangibly / motivation, hope, adaptation with CHF

- Acceptance and support from health care professional / adaptation to new life leads to adherent to appropriate self-care behaviors ( physical activity and adherence to prescribed instructions)

- Respect for patients / Increasing their knowledge and Participate in decision making

- Sympathy, reflective listening, acknowledging cultural values / engage patients to enhance their knowledge, skill and motivation to fallow self-care rules

- Information / building skills of self-care in patients -Stimulating supporting resources / collaboration and participate in care programs

- Social activity and mutual support / motivation

- Education especially with patients' own language / adherence to regimen

- Social support, satisfaction with health system delivery/Positive outlook, perform self-care behavior

- Simplicity of self-care/ daily weighing and symptom monitoring,

- Understanding reason for self-care / perceived health care roles, perceived benefit associated with physical activity 
Table 3 Barriers and facilitators to self-care in chronic heart failure (Continued)

\begin{tabular}{|c|c|c|}
\hline \multirow[t]{4}{*}{ Falk et al. (2007) Sweden } & $\begin{array}{l}\text { Cultural issues, health seeking behaviours / } \\
\text { adherence to regimen }\end{array}$ & $\begin{array}{l}\text { - Trust family and formal care givers / following } \\
\text { instructions }\end{array}$ \\
\hline & & - Social activity/ physical activity \\
\hline & & $\begin{array}{l}\text { - perceiving the risk of withdrawing medicine / } \\
\text { adherence to medicine and regimen }\end{array}$ \\
\hline & & - Facility ( Care availability) / care - seeking \\
\hline Davidson et al. (2007) Australia & $\begin{array}{l}\text { - Cognition problems due to CHF symptom / } \\
\text { weighting, regiment, taking water pill }\end{array}$ & \\
\hline \multirow[t]{3}{*}{ Riegel et al. (2007) USA } & - Depression / motivation for self-care & \\
\hline & $\begin{array}{l}\text { - Poor family functioning / self-care } \\
\text { maintenance and management }\end{array}$ & \\
\hline & $\begin{array}{l}\text { - Denial of illness/ adherence to regimen and } \\
\text { treatment }\end{array}$ & \\
\hline \multirow[t]{5}{*}{ Kaholokula et al. (2008) USA } & - Hopelessness/ decision making & \\
\hline & $\begin{array}{l}\text { - Lack of family knowledge/ misconception } \\
\text { about treatment preference }\end{array}$ & \\
\hline & - Financial -burden / adherence to regimen & \\
\hline & $\begin{array}{l}\text { - Lack of trust physicians / medical using } \\
\text { herbal medicine }\end{array}$ & \\
\hline & $\begin{array}{l}\text { - Lack of information about CHF symptom / } \\
\text { symptom recognition and help-seeking }\end{array}$ & \\
\hline \multirow[t]{2}{*}{ Rodriguez et al. (2008) USA } & $\begin{array}{l}\text { - Comorbidity / symptom recognition } \\
\text { (confusion about cause of symptoms ) }\end{array}$ & \\
\hline & $\begin{array}{l}\text { - Lack of knowledge / sodium restriction } \\
\text { and decision making }\end{array}$ & \\
\hline \multirow[t]{3}{*}{ Sheahan \& Fields (2008) USA } & - Loneliness/ motivation to care & - Living with family / motivation for adherence to \\
\hline & - Cultures / dietary behaviours & ime \\
\hline & $\begin{array}{l}\text { - Lack of experience / medical adherence } \\
\text { and symptom recognition }\end{array}$ & \\
\hline \multirow[t]{2}{*}{ Dickson et al. (2008) USA } & $\begin{array}{l}\text { - Side effect of medicine and interfere in } \\
\text { work and normal life / medical adherence }\end{array}$ & $\begin{array}{l}\text { - Long time experiences of HF / self-management } \\
\text { and symptom monitoring }\end{array}$ \\
\hline & $\begin{array}{l}\text { Traditional education \& insufficient skill in } \\
\text { educators / developingself- maintenance } \\
\text { (Diet, diuretic titration and exercise, low salt diet) }\end{array}$ & \\
\hline Dickson \& Riegel (2009) USA & $\begin{array}{l}\text { - Complexity of self-care rules and no } \\
\text { agreement between doctors and patients } \\
\text { about this difficulty, hopelessness / fitting } \\
\text { prescribed regimen into daily life all aspects } \\
\text { of self-care were affected) }\end{array}$ & \\
\hline Granger et al. (2009) USA & $\begin{array}{l}\text { - Side effects of medicine interfering with } \\
\text { social activities / medical adherence }\end{array}$ & \\
\hline \multirow[t]{5}{*}{ Clark et al. (2009) USA } & - HF symptoms/ symptom recognition & \\
\hline & $\begin{array}{l}\text { - Lack of knowledge / self-management e.g. } \\
\text { help-seeking and }\end{array}$ & \\
\hline & - Lack of confidence / self-management & \\
\hline & - Personal values linked to culture/ help-seeking & \\
\hline & $\begin{array}{l}\text { - Female, depression/ self-care confidence, } \\
\text { decision making and interpreting symptoms }\end{array}$ & \\
\hline \multirow[t]{2}{*}{ Riegel et al. (2010a) USA } & - Poor family support/ symptom -management & $\begin{array}{l}\text { - Male/ self-care confidence and symptom } \\
\text { recognition }\end{array}$ \\
\hline & - Complexity medicine / adherence to medicine & $\begin{array}{l}\text { - Family support, hopefulness/ symptom } \\
\text { management }\end{array}$ \\
\hline
\end{tabular}


Table 3 Barriers and facilitators to self-care in chronic heart failure (Continued)

\begin{tabular}{|c|c|c|}
\hline \multirow[t]{3}{*}{ Ming et al. (2011) Malaysia } & $\begin{array}{l}\text { - Limited communication of doctors / } \\
\text { adherence to medication }\end{array}$ & $\begin{array}{l}\text { Family support/ self-care confidence and } \\
\text { adherence to treatment }\end{array}$ \\
\hline & $\begin{array}{l}\text { - Difficulty in remembering/ adherence to } \\
\text { medication and regimen }\end{array}$ & \\
\hline & $\begin{array}{l}\text { - Cultural issues / adherence to diet } \\
\text { (having favorite food) }\end{array}$ & \\
\hline \multirow[t]{4}{*}{ Dickson et al. (2012 / published online) USA } & $\begin{array}{l}\text { - Knowledge /symptom monitoring and } \\
\text { management (e.g. attributing CHF to stress) }\end{array}$ & $\begin{array}{l}\text { - Social support / adherence to regimen and } \\
\text { self- confidence }\end{array}$ \\
\hline & & $\begin{array}{l}\text { - Financial support and access to facilities / } \\
\text { adherence to medication, }\end{array}$ \\
\hline & & - Spirituality / motivate to care for themselves \\
\hline & & $\begin{array}{l}\text { - Some cultural belief leading to strong familial } \\
\text { support / engaging in self-care maintenance and } \\
\text { self-care management, e.g. preparing unsalted } \\
\text { food by family. }\end{array}$ \\
\hline
\end{tabular}

confidence, while positive belief in the future could serve as a catalyst for self-care(Falk et al. 2007; Martensson et al. 1997; Kaholokula et al. 2008).

According to the results, cultural beliefs and personal values might lead to a misguided conception of $\mathrm{CHF}$ (Dickson et al. 2012), difficulty with adherence to a healthy diet(Sheahan \& Fields 2008; Dickson et al. 2012), preventing help-seeking (Clark et al. 2009), non-adherence to recommendations and health messages(Eldh et al. 2006; Kaholokula et al. 2008). On the other hand, cultural beliefs and personal values may support some aspects of self-care such as medication adherence (Dickson et al. 2012).

The influence of gender on self-care was explored by only one study (Riegel et al. 2010a). Although males and females exhibited equal medical adherence (self-care maintenance), females had lower self-care confidence and engaged less in self-care management and showed less accurate symptom interpretation than males (Riegel et al. 2010a). However, males had stronger social support than women and more positive perspectives on their lives and their ability to perform a self-care role than women (Riegel et al. 2010a). Cognitive decline and short term memory loss were important barriers to adherence to treatment and self-car plans especially in older people with CHF (Riegel \& Carlson 2002; Granger et al. 2009; Ming et al. 2011; Dickson et al. 2012). Age as a direct influencing factor was not reported by the reviewed studies, though it was referred when speaking about disabilities and comorbidities (Riegel \& Carlson 2002).

\section{Facilitators and barriers related to environment and health care givers}

Supportive environments, either mutual from other patients or from family, neighbours, nurses and physicians facilitated self-care in terms of self-care confidence, adaptation with disease and reducing anxiety, adherence to treatment and food regimen, symptom management, positive outlook, and motivation to obtain information and care for own selves (Falk et al. 2007; Martensson et al. 1997; Riegel \& Carlson 2002; Scotto 2005; Riegel et al. 2006; Schnell et al. 2006; Ming et al. 2011; Dickson et al. 2012) and poor self-care was associated with poor family support (Riegel et al. 2007; Riegel et al. 2010a). Also, respecting patients (Schnell et al. 2006) and acknowledging their values encouraged them to follow health regimens (Eldh et al. 2006; Riegel et al. 2006). In contrast, poor communication skill of care givers (Ming et al. 2011) and lack of trust health care professionals (Clark et al. 2009) prevented patients from seeking information required for self-care. Applying traditional teaching methods (Dickson \& Riegel 2009) and not spending sufficient time with patients to train them about self-care (Kaholokula et al. 2008) or a failure to teach them practically (Granger et al. 2009) were other reported problems.

\section{Discussion}

This review identified factors influencing self-care in patients with CHF. However, only CHF symptoms and comorbidity, knowledge, environmental support, and psychological factors are discussed here due to their frequency.

\section{Symptoms of chronic heart failure and comorbidities; complexity of symptom recognition}

In recognizing and managing their symptoms, patients with $\mathrm{CHF}$ faced many difficulties and problems. First, confusing symptoms of CHF and cognitive impairment, especially in elderly patients, may reduce individuals' mental ability to recognize their symptoms and develop effective symptom management as a core for self-care (Ming et al. 2011). Second, illness severity may limit the capacity of a patient to manage symptoms. As an example, exhaustion and shortness of breath limited the individual's ability not only for engaging in daily physical activity recommended 
in self-care instructions (e.g. 30minutes exercise daily) (Riegel et al. 2009) but stopped them managing when an exacerbation of CHF occurs (Granger et al. 2009; Ming et al. 2011). Third, symptoms might be attributed to other health problems and patients became confused in seeking to distinguish the reason and origin of their symptoms. In such situations, patients failed to take the correct action. As an example patients with CHF suffering, from arthritis might became confused about whether their swollen ankles are due to heart failure or arthritis (Riegel et al. 2009).

Furthermore, functional limitation may be compounded by other chronic problems such as forgetfulness, memory loss, diabetes, arthritis and chronic obstructive pulmonary disease in elderly patients (Martensson et al. 1997; Riegel \& Carlson 2002 ; Riegel \& Carlson 2002; Clark et al. 2009). Complex collections of problems produced frustration and feelings of hopelessness for patients, their families and even caregivers (Rogers et al. 2000; Riegel et al. 2007; Granger et al. 2009). It also is not easy for these patients to adhere to medical prescriptions and diet regimes (Dickson et al. 2012).

\section{Insufficient knowledge}

Misconception due to insufficient knowledge was associated with self-care challenges in all aspects including medical and dietary adherence, (Rogers et al. 2000; Rucker-Whitaker et al. 2006), weighing (Riegel \& Carlson 2002), symptom recognition (Horowitz et al. 2004), treatment performance (Kaholokula et al. 2008) and help-seeking (Rodriguez et al. 2008). Although these results were not unexpected findings (Field et al. 2006), it elucidated and supported many other studies that considered knowledge a critical foundation for self-care in patients with CHF (Toman et al. 2001; Artinian et al. 2002; Bushnell 1992; Wright et al. 2003; Miche et al. 2003). Insufficient information not only directly prohibited patients from understanding and applying instructions, but also introduced other barriers to self-care in patients with CHF (Kaholokula et al. 2008; Clark et al. 2009; Dickson et al. 2012). For instance, consumption of salty foods recognized by some investigators as a behavior associated with cultural beliefs and/or social norms might simply be a manifestation of ignorance due to insufficient knowledge about the pathophysiology of CHF or the role of self-maintenance. Having sufficient knowledge and accurate information was necessary but not sufficient for behaviour change. Many patients were not able to incorporate their knowledge into their daily lives (Granger et al. 2009) because they were not equipped with practical skills (Eldh et al. 2006; Dickson \& Riegel 2009).

Important factors associated with the failure of self-care programs included inadequate educational approach due to unskilled health educators (Eldh et al. 2006; Albert et al. 2002) or a gap in provider knowledge of self-care instructions (Lainscak et al. 2011), applying too general instruction for specific situations (Dickson et al. 2008) or inappropriate educational program-planning (Boren et al. 2009), lack of assessment of self-care educational programs (Lainscak et al. 2011). The majority of educational programs were short duration interventions without sufficient on-going support from providers to continue the programs and build self-care skills (Boren et al. 2009; De Lusignan et al. 2001; Sethares \& Elliott 2004). Only half of patients were given comprehensive information about selfcare monitoring and self-care maintenance (Boren et al. 2009). Considering the economic effectiveness of self-care (Jeon et al. 2009) researchers and health policymakers might well recommend applying more resources to evaluating specific programs for specific conditions of patients.

\section{Environmental factors and cultural beliefs; motivators and hinders}

There is evidence that patients with CHF suffered from social isolation (Jeon et al. 2010) that is associated with higher mortality in CHF (Horne \& Weinman 1999). Although Sayers et al. pointed out that social support is not strongly associated with better self-care (Sayers et al. 2008), a review study stated that social support was prognostic in patients with HF (Ka \& Lip 2002). The results of the current study showed that a supportive environment is critical for creating positive feelings and improving virtually all self-care components in patients with CHF (Falk et al. 2007; Martensson et al. 1997; Riegel \& Carlson 2002; Scotto 2005; Riegel et al. 2006; Schnell et al. 2006; Ming et al. 2011; Dickson et al. 2012). Patients who have an opportunity to share their problems and those who participate in social activities manifest better self-care (Falk et al. 2007; Rucker-Whitaker et al. 2006). By way an example, eating alone reduced one's motivation to cook and share meals resulting in an increased consumption of 'microwave dinners' often with high sodium content (Sheahan \& Fields 2008).

Cultural beliefs (another theme that emerged from this review) might give patients a misguided conception of $\mathrm{CHF}$, leading them to think, for example, that CHF is due to stress or simply associated with old age (Dickson et al. 2012). As a result, patients attempted to overcome a stressful situation by not following medical instruction. In addition, cultural preferences (e.g. favourite foods) often caused difficulty with adherence to a healthy diet (e.g. high salt consumption) (Sheahan \& Fields 2008). However, cultural beliefs and personal values may support some aspects of self-care such as medication adherence. Dickson and her colleagues reported that spirituality influences self-care positively (Dickson et al. 2012).

In order to manage contextual problems such as cultural issues, health providers and educators needed to have good communication skills including reflective 
listening, empathy and acknowledging patients' personal values (Jeon et al. 2010; Gilbert \& Hayes 2009). Effective communication skills and trust have a reciprocal relationship; by improving one the other will be strengthened (Halpert \& Godena 2011; Thomas 2011). However, according our findings, poor doctor-patient communication was an important barrier to self-care in patients with CHF (Kaholokula et al. 2008; Ming et al. 2011). Horne and Weinman found that medication beliefs are a stronger predictor of adherence than sociodemographic factors and clinical situation (Kramer 2010). A lack of faith in health care professionals along with personal values and cultural beliefs may stop patients from seeking help when symptoms worsen because the symptoms were culturally perceived to be uncontrollable and have to be accepted stoically (Clark et al. 2009).

\section{Psychological factors}

Evidence shows that depression in patients with CHF is much more prevalent than general population (MacMahon \& Lip 2002). On the other hand, depression resulting in lack of energy leads to unwanted effects on self-care (Turner \& Kelly 2000). In addition, depression may increase the risk of death in this group of patients (Horne \& Weinman 1999). Whereas experiencing positive emotions allows people to engage in behaviours that protect their positive state (Frantz 2004). The current study indicated that hopelessness and depression was observed as a significant problem for patients with CHF, especially lonely women (Riegel et al. 2010a). This influenced selfcare confidence, symptom recognition (self-care management), though, adherence to medicine (self-care maintenance) was not affected by level of depression (Riegel et al. 2010a). Providing circumstances in which patients may continue with their leisure activities and assisting patients to have a better quality of life can result in improved moods and self-care ability.

Patients with CHF facing stressful situations and changes in life circumstances, employ a range of defence mechanisms and coping strategies some enabling and others less so (Kramer 2010; Telford et al. 2006). Telford and colleagues found that common reactions of patients suffering from chronic diseases include denial then acceptance (Telford et al. 2006). The current review showed that avoidance and denial reduce the capability of patients to care for themselves (Riegel \& Carlson 2002; Eldh et al. 2006; Rucker-Whitaker et al. 2006). Disavowal (palliating the emotional strain at the same time as affirming their health) assisted patients to cope with their mental stresses without ignoring the reality of their disease (Buetow et al. 2001). Acceptance is a coping strategy that had both positive (Falk et al. 2007; Buetow et al. 2001; Riegel \& Carlson 2002) and negative (Buetow et al. 2001; Riegel \& Carlson 2002; Scotto 2005) effects on different personality and living in various cultural contextual.

\section{Limitations}

Although there was an emerging literature, only rarely did studies report using the classic qualitative methodologies such as ethnography, grounded theory, phenomenology etc. Consequently, categorization of studies (that usually facilitates both evaluating articles and also amalgamating and analyzing data comprehensively) was difficult. Also, many authors had reported little raw data. In addition, factors such as socioeconomic situation and education level were not explored extensively and there were minimal data on the influence of age, gender, and the role of specific comorbidities. Virtually nothing has been published on the value or otherwise of lay versus professional educators. Furthermore, facilitators of self-care were not investigated as much as barriers.

\section{Conclusion}

This review indicates that self-care is a complex and multi-faceted phenomenon that needs a comprehensive consideration of patients including their emotional situation, psychological characters, physical abilities, family support, living facilities, comorbidities (especially cognitive function) and their ability for learning. Insufficient knowledge about CHF, symptom recognition and ways of self-care along with hopelessness and psychological problems limited their abilities for an effective self-care. A supportive environment, motivation and adequate care programs using effective educational methods that build self-care skills, should be recommended to health care providers and families. Nevertheless, further research is required to address the barriers and facilitators of self- care in patients with CHF.

\section{Competing interests}

The authors declare that they have no competing interests.

\section{Authors' contributions}

The bibliography of retrieved papers was also searched to identify potential publications. Three people were involved in searching literature and selecting papers, one (SS) in the first stage and two (SRL and PMD) in the second stage when applying criteria and analyzing results. All authors read and approved the final manuscript.

\section{Acknowledgment}

We wish to appreciate Dr. Farid Najafi, Associate professor of KUMS for his comments on this manuscript. Also, we thank Dr. Justin McNab, research Fellow of Menzies Centre for health policy, University of Sydney, for his help in developing critical appraisal criteria for the assessment of reviewed studies.

\section{Author details}

${ }^{1}$ Victor Coppleson Building - D02, Menzies Center for Health Policy, Medical School, The University of Sydney, Sydney, Australia. ${ }^{2}$ School of Health, Kermansha University of Medical Sciences, Kermanshah, Iran. ${ }^{3}$ Centre for Cardiovascular \& Chronic Care, Faculty of Health, University of Technology, Sydney, Australia. 
Received: 29 May 2013 Accepted: 8 July 2013

\section{Published: 16 July 2013}

\section{References}

AlHW (2011) Cardiovascular disease: australian facts 2011 cardiovascular disease series, vol 35. AlHW, Canberra

Albert NM, Collier S, Sumodi V, Wilkinson S, Hammel JP, Vopat L, Willis C, Bittel B (2002) Nurses's knowledge of heart failure education principles. Heart Lung 31(2):102-112

Anguita Sanchez M, Crespo Leiro MG, de Teresa Galvan E, Jimenez Navarro M, Alonso-Pulpon L, Muniz Garcia J (2008) Prevalence of heart failure in the spanish general population aged over 45 years. The PRICE study. Rev Esp Cardiol 61(10):1041-1049

Artinian NT, Magnan M, Christian W, Lange MP (2002) What do patients know about their heart failure? Appl Nurs Res 15(4):200-208

Barnett-Page E, Thomas J (2009) Methods for the synthesis of qualitative research: a critical review. BMC Med Res Methodol 9(1):59

Berry C, Murdoch DR, McMurray JJV (2001) Economics of chronic heart failure. Eur J Heart Fail 3(3):283-291. doi:10.1016/s1388-9842(01)00123-4

Boren SA, Wakefield BJ, Gunlock TL, Wakefield DS (2009) Heart failure selfmanagement education: a systematic review of the evidence. Int J Evid Based Healthc 7(3):159-168. doi:10.1111/j.1744-1609.2009.00134.x

Buetow S, Goodyear-Smith F, Coster G (2001) Coping strategies in the self-management of chronic heart failure. Fam Pract 18(2):117-122

Bushnell FK (1992) Self-care teaching for congestive heart failure patients. J Gerontol Nurs 18(10):27-32

CG (2010) Evaluating the quality of qualitative research. Nord J Music Ther 19(1):1-2

Chen LM, Jha AK, Guterman S, et al. (2010) The hospital cost of care, quality of care, and readmission rates: penny-wise and pound-foolish? Arch Intern Med 170(4):340-346

Clark AM, Freydberg CN, McAlister FA, Tsuyuki RT, Armstrong PW, Strain LA (2009) Patient and informal caregivers' knowledge of heart failure: necessary but insufficient for effective self-care. Eur J Heart Fail 11(6):617-621. doi:10.1093/eurjhf/hfp058

Collingridge DS, Gantt EE (2008) The Quality of Qualitative Research. Am J Med Qual 23(5):389-395

Davidson PM, Macdonald P, Moser DK, Ang E, Paull G, Choucair S, Daly J, Gholizadeh L, Dracup K (2007) Cultural diversity in heart failure management: findings from the DISCOVER study (Part 2). Contemp Nurse 25(1-2):50-61

De Lusignan S, Wells S, Johnson P, Meredith K, Leatham E (2001) Compliance and effectiveness of 1 year's home telemonitoring. The report of a pilot study of patients with chronic heart failure. Eur J Heart Failu 3(6):723-730. doi:10.1016/s1388-9842(01)00190-8

Dickson W, Riegel B (2009) Are we teaching what patients need to know? building skills in heart failure self-care. Heart Lung 38(3):253-261

Dickson W, Deatrick JA, Riegel B (2008) A typology of heart failure self-care management in non-elders. Eur J Cardiovasc Nurs 7(3):171-181. doi:10.1016/j.ejcnurse.2007.11.005

Dickson WMM, Howe A, Schipper J, Katz SM (2012) Sociocultural influences on heart failure self-care among an ethnic minority black population. J Cardiovasc Nurs 27

Ditewig JB, Blok H, Havers J, van Veenendaal H (2010) Effectiveness of self-management interventions on mortality, hospital readmissions, chronic heart failure hospitalization rate and quality of life in patients with chronic heart failure: a systematic review. Patient Educ Couns 78(3):297-315

Dixon-Woods MAS, Jones D, Young B, Sutton A (2005) Synthesising qualitative and quantitative evidence: a review of possible methods. J Health Serv Res Policy 10(1):45-53

Eldh AC, Ehnfors M, Ekman I (2006) The meaning of patient participation for patients and nurses at a nurse-led clinic for chronic heart failure. Eur J Cardiovasc Nurs 5(1):45-53

Falk S, Wahn A-K, Lidell E (2007) Keeping the maintenance of daily life in spite of chronic heart failure; a qualitative study. Eur J Cardiovasc Nurs 6(3):192-199

Field K, Ziebland S, McPherson A, Lehman R (2006) 'Can I come off the tablets now?' A qualitative analysis of heart failure patients' understanding of their medication. Fam Pract 23(6):624-630. doi:10.1093/fampra/cml036

Frantz AK (2004) Breaking down the barriers to heart failure patient self-care. Home Healthc Nurse 22(2):109-115

Gilbert DA, Hayes E (2009) Communication and outcomes of visits between older patients and nurse practitioners. Nurs Res 58(4):283-293
Go AS, Mozaffarian D, Roger VL, Benjamin EJ, Berry JD, Borden WB, Bravata DM, Dai S, et al. (2013) Heart disease and stroke statistics—2013 update: a report from the american heart association. Circulation 127(1):e6-e245. doi:10.1161/CIR.0b013e31828124ad

Grady KL (2008) Self-care and quality of life outcomes in heart failure patients. J Cardiovasc Nurs 23(3):285-292

Granger BB, Sandelowski M, Tahshjain H, Swedberg K, Ekman I (2009) A qualitative descriptive study of the work of adherence to a chronic heart failure regimen: patient and physician perspectives. J Cardiovasc Nurs 24(4):308-315

Halpert A, Godena E (2011) Irritable bowel syndrome patients' perspectives on their relationships with healthcare providers. Scand J Gastroenterol 46(7-8):823-830

Heidenreich PA, Trogdon JG, Khavjou OA, Butler J, Dracup K, Ezekowitz MD, Finkelstein EA, et al. (2011) Forecasting the future of cardiovascular disease in the united states. Circulation 123(8):933-944. doi:10.1161/CIR.0b013e31820a55f5

Hertzog MA, Pozehl B, Duncan K (2010) Cluster analysis of symptom occurrence to identify subgroups of heart failure patients: a pilot study. J Cardiovasc Nurs 25(4):273-283

Horne R, Weinman J (1999) Patients' beliefs about prescribed medicines and their role in adherence to treatment in chronic physical illness. J Psychosom Res 47(6):555-567. doi:10.1016/s0022-3999(99)00057-4

Horowitz CR, Rein SB, Leventhal H (2004) A story of maladies, misconceptions and mishaps: effective management of heart failure. Soc Sci Med 58(3):631-643

Jeon Y-H, Essue B, Jan S, Wells R, Whitworth JA (2009) Economic hardship associated with managing chronic illness: a qualitative inquiry. BMC Health Serv Res 9:182

Jeon Y-H, Kraus S, Jowsey T, Glasgow N (2010) The experience of living with chronic heart failure: a narrative review of qualitative studies. BMC Health Serv Res 10(1):77

Kaholokula JK, Saito E, Mau MK, Latimer R, Seto TB (2008) Pacific Islanders' perspectives on heart failure management. Patient Educ Couns 70(2):281-291

Kent B, Fineout-Overholt E (2008) Using meta-synthesis to facilitate evidencebased practice. Worldviews Evid Based Nurs 5(3):160-162. doi:10.1111/j.1741-6787.2008.00133.x

Kitto SC, Chesters J, Grbich C (2008) Quality in qualitative research. Med J Aust 188(4):243-246

Klersy C, De Silvestri A, Gabutti G, Raisaro A, Curti M, Regoli F, Auricchio A (2011) Economic impact of remote patient monitoring: an integrated economic model derived from a meta-analysis of randomized controlled trials in heart failure. Eur J Heart Fail 13(4):450-459. doi:10.1093/eurjhf/hfa232

Kramer U (2010) Oping and defence mechanisms: What's the difference?second act. Psychol Psychother 83(2):207-221

Kuper ALL, Levinson W (2008) Critically appraising qualitative research. BMJ 337:687-692

Lainscak M, Blue L, Clark AL, Dahlström U, Dickstein K, Ekman I, et al. (2011) Self-care management of heart failure: practical recommendations from the Patient Care Committee of the Heart Failure Association of the European Society of Cardiology. Eur J Heart Fail 13(2):115-126

MacMahon K, Lip G (2002) Psychological factors in heart failure: a review of the literature. Arch Intern Med 162(5):509-516. doi:10.1001/archinte.162.5.509

Martensson J, Karlsson JE, Fridlund B (1997) Male patients with congestive heart failure and their conception of the life situation. J Adv Nurs 25(3):579-586

Masoudi FA, Havranek EP, Krumholz HM (2002) The burden of chronic congestive heart failure in older persons: magnitude and implications for policy and research. Heart Fail Rev 7(1):9-16. doi:10.1023/a:1013793621248

Miche E, Herrmann G, Wirtz U, Laki H, Barth M, Radzewitz A (2003) Effects of education, self-care instruction and physical exercise on patients with chronic heart failure. Z Kardiol 92(12):985-993

Ming LC, Hassal MA, Shafie AA, Awaisu A, Hadi MA, Al-Haddad M (2011) Perspectives of heart failure patients in Malaysia towards medications and disease state management: Findings from a qualitative study. J Public Health 19(6):569-577

Moser D, Dickson V, Jaarsma T, Lee C, Stromberg A, Riegel B (2012) Role of self-care in the patient with heart failure. Curr Cardiol Rep 14(3):265-275. doi:10.1007/s11886-012-0267-9

Murray J (1998) Qualitative methods. Int Rev Psychiatry 10(4):312-316

Muzzarelli S, Brunner-La Rocca H, Pfister O, Foglia P, Moschovitis G, Mombelli G, Stricker $\mathrm{H}$ (2010) Adherence to the medical regime in patients with heart failure. Eur J Heart Fail 12(4):389-396

Myers M (2000) Qualitative research and the generalizability question: standing firm with proteus. Qual Rep 4(3/4). doi:http://www.nova.edu/ssss/QR/QR4-3/myers.html 
Powell LH, Calvin JE, Jr, Mendes de Leon CF, Richardson D, Grady KL, Flynn KJ, Rucker-Whitaker CS, Janssen I, Kravitz G, Eaton C, Heart Failure A, Retention Trial I (2008) The heart failure adherence and retention trial (HART): design and rationale. Am Heart J 156(3):452-460

Riegel B, Carlson B (2002) Facilitators and barriers to heart failure self-care. Patient Educ Couns 46(4):287-295

Riegel B, Dickson W, Hoke L, McMahon JP, Reis BF, Sayers S (2006) A motivational counseling approach to improving heart failure self-care: mechanisms of effectiveness. J Cardiovasc Nurs 21(3):232-241

Riegel B, Vaughan Dickson V, Goldberg LR, Deatrick JA (2007) Factors associated with the development of expertise in heart failure self-care. Nurs Res 56(4):235-243

Riegel B, Lee CS, Dickson W, Carlson B (2009) An update on the self-care of heart failure index. J Cardiovasc Nurs 24(6):485-497. doi:10.1097/ JCN.0b013e3181 b4baa0

Riegel B, Dickson W, Kuhn L, Page K, Worrall-Carter L (2010a) Gender-specific barriers and facilitators to heart failure self-care: a mixed methods study. Int J Nurs Stud 47(7):888-895

Riegel B, Dickson W, Cameron J, Johnson JC, Bunker S, Page K, Worrall-Carter L (2010b) Symptom recognition in elders with heart failure. J Nurs Scholarsh 42(1):92-100

Rodriguez KL, Appelt CJ, Switzer GE, Sonel AF, Arnold RM (2008) "They diagnosed bad heart": a qualitative exploration of patients' knowledge about and experiences with heart failure. Heart Lung 37(4):257-265

Rogers AE, Addington-Hall JM, Abery AJ, McCoy ASM, Bulpitt C, Coats AJS, Gibbs JSR (2000) Knowledge and communication difficulties for patients with chronic heart failure: qualitative study. BMJ 321 (7261):605-607. doi:10.1136/bmj.321.7261.605

Rucker-Whitaker C, Flynn KJ, Kravitz G, Eaton C, Calvin JE, Powell LH (2006) Understanding African-American participation in a behavioral intervention: results from focus groups. Contemp Clin Trials 27(3):274-286

Sandelowski M, Barroso J (2003) Creating metasummaries of qualitative findings. Nurs Res 52(4):226-233

Sandelowski MDS, Emden C (1997) Focus on qualitative methods qualitative metasynthesis: issues and techniques. Res Nurs Health 20:365-367

Sayers SL, Riegel B, Pawlowski S, Coyne JC, Samaha FF (2008) Social support and self-care of patients with heart failure. Ann Behav Med 35(1):70-79. doi:10.1007/s12160-007-9003-x [doi]

Schnell KN, Naimark BJ, McClement SE (2006) Influential factors for self-care in ambulatory care heart failure patients: a qualitative perspective. Can $J$ Cardiovasc Nurs 16(1):13-19

Scotto CJ (2005) The lived experience of adherence for patients with heart failure. J Cardiopulm Rehabil 25(3):158-163

Sethares KA, Elliott K (2004) The effect of a tailored message intervention on heart failure readmission rates, quality of life, and benefit and barrier beliefs in persons with heart failure. Heart Lung 33(4):249-260

Sheahan SL, Fields B (2008) Sodium dietary restriction, knowledge, beliefs, and decision-making behavior of older females. J Am Acad Nurse Pract 20(4):217-224

Solomon JMYMJ (2009) How to critically appraise an article. Nat Clin Pract Gastroenterol Hepatol 6:82-91

Telford K, Kralik D, Koch T (2006) Acceptance and denial: implications for people adapting to chronic illness: literature review. J Adv Nurs 55(4):457-464

Thomas JRCA (2011) Women with heart failure Are at high psychosocial risk: a systematic review of How Sex and gender influence heart failure self-care. Cardiolo Res Prac 2011:918973-918976. doi:10.4061/2011/918973

Thorne S, Jensen L, Kearney MH, Noblit G, Sandelowski M (2004) Qualitative metasynthesis: reflections on methodological orientation and ideological agenda. Qual Health Res 14(10):1342-1365. doi:10.1177/1049732304269888

Toman C, Harrison MB, Logan J (2001) Clinical practice guidelines: necessary but not sufficient for evidence-based patient education and counseling. Patient Educ Couns 42(3):279-287

Turner J, Kelly B (2000) Emotional dimensions of chronic disease. West J Med 172(2):124-128

Wright SP, Walsh H, Ingley KM, Muncaster SA, Gamble GD, Pearl A, Whalley GA, Sharpe N, Doughty RN (2003) Uptake of self-management strategies in a heart failure management programme. Eur J Heart Fail 5(3):371-380

doi:10.1186/2193-1801-2-320

Cite this article as: Siabani et al:: Barriers and facilitators to self-care in chronic heart failure: a meta-synthesis of qualitative studies. SpringerPlus $20132: 320$

\section{Submit your manuscript to a SpringerOpen ${ }^{\circ}$ journal and benefit from:}

- Convenient online submission

- Rigorous peer review

- Immediate publication on acceptance

- Open access: articles freely available online

- High visibility within the field

- Retaining the copyright to your article

Submit your next manuscript at $\gg$ springeropen.com 